\title{
Understanding phosphorus dynamics on wheat plant under split-root system in alkaline soil
}

\author{
Rubya Shabnam ${ }^{1}$ and Md Toufiq lqbal ${ }^{2 *}$
}

\author{
*Correspondence: \\ toufiq_iqbal@yahoo.com \\ ${ }^{2}$ Department of Agronomy \\ and Agriculture Extension, \\ Faculty of Agriculture, \\ Rajshahi University, Rajshahi, \\ Bangladesh \\ Full list of author information \\ is available at the end of the \\ article
}

\begin{abstract}
Plants are not uniform in their nutritional requirements, most of them survive under adverse conditions of humidity, temperature and nutrients, because they are genetically adapted to their habitat and even some varieties of the same species present differences in absorption, translocation, accumulation and nutrient use. This study is aimed at examining the phosphorus (P) status and $\mathrm{P}$ distribution in the different parts of wheat (Triticum aestivum L.) plant, root and shoot growth response in a split-root soil culture in alkaline soil. The soil having pH 7.9 was collected from the alkaline region of Bangladesh. $\mathrm{KH}_{2} \mathrm{PO}_{4}$ was used as the source of phosphorus for the different level of $\mathrm{P}$ applications. Two recently BARI developed wheat varieties namely BARI GOM 25 and BARI GOM 26 were used as testing plants with three replications. Result showed the growth parameter increased with the increase of $\mathrm{P}$ application. Likewise, $\mathrm{P}$ uptake by wheat seedlings also increases with the elevated $P$ application. However, no significant differences were observed between wheat varieties irrespective of growth and $P$ uptake by wheat seedlings. Moreover, elevated P concentrations in the shoot of wheat plants probably provided more $\mathrm{P}$ for shoot unloading of $\mathrm{P}$ and for $\mathrm{P}$ assimilation in the controlled roots, resulting in increased $P$ concentrations in the roots of wheat plants, that means, translocation of $\mathrm{P}$ in the roots. These findings indicate that the added soluble $P$ increases the absorption of nutrients from the soil solution. However, application of elevated $\mathrm{P}$ is efficient both for increasing shoot development and root growth and plays significant role in the phosphorus dynamics within the wheat plants in split root system in alkaline soil.
\end{abstract}

Keywords: Split-root system, Phosphorus translocation, P application in alkaline soil

\section{Background}

Phosphorus (P) availability in most calcareous soils is very low, limiting crop production, because of the formation of sparingly soluble phosphate compounds with $\mathrm{Ca}$ in alkaline soils (Marschner 1995). It is estimated that more than $30 \%$ of soils cultivated globally suffer from $\mathrm{P}$ deficiency stress, and that the world reserves of $\mathrm{P}$ might be depleted by 2050 (Batjes 1997; Vance et al. 2003). Phosphorus deficiency is also a critical nutritional problem in plant growth as it plays a key role in plant growth and is the major plant growth-limiting nutrient despite its abundance in soils in both inorganic and organic forms (Gyaneshwar et al. 1999). It is absorbed by the plants, in orthophosphate 
$\left(\mathrm{H}_{2} \mathrm{PO}_{4}{ }^{-}\right.$and $\mathrm{HPO}_{4}{ }^{2-}$ ) forms (Hinsinger 2001). Phosphorus is important in several physiological processes of plants, especially in photosynthesis, carbon metabolism, and membrane formation (Wu et al. 2005). The concentrations of inorganic P in soil solution are, however, typically very low, due to inorganic P's propensity to bind strongly to soil surfaces or form insoluble complexes with cations. This means that inorganic P is often a limiting factor in plant growth and development. This has resulted in a large number of developmental traits amongst plant species that can enhance inorganic P uptake. Physiologically these include the modulation of root elongation (Sánchez-Calderón et al. 2005), branching (Linkohr et al. 2002; López-Bucio et al. 2002), and root hair density (Ma et al. 2001). The root system may also act to enhance inorganic P uptake by exuding protons (Hinsinger 2001), organic acid anions (Ryan et al. 2001), and phosphatases (Tadano and Sakai 1991) into the rhizosphere, or by the formation of symbioses with arbuscular mycorrhizas or ectomycorrhizas (Péret et al. 2011; Smith et al. 2011). Phosphorus is readily translocated within the plants, moving from older to younger tissues as the plant forms cells and develops roots, stems and leaves. Moreover, in inorganic $\mathrm{P}$-deficient plants the restricted supply of $\mathrm{P}$ to the shoots from the roots via the xylem is supplemented by increased mobilization of stored $\mathrm{P}$ in the older leaves and retranslocation to both the younger leaves and growing roots. To understand the mechanisms controlling these traits is, therefore, of great importance in the pursuit of improved crop inorganic P uptake.

Keeping in view of the above facts, the study aims at following objectives: to understand mechanisms involved in the utilization of inorganic phosphorus by wheat plant under various split-root systems in alkaline soil and to quantify how translocated phosphorus effects on wheat plant within split-root system under different $\mathrm{P}$ efficient condition.

\section{Methods}

\section{Experimental design}

Soil and plant

In this study, alkaline soil was used as experimental soil. The alkaline soil collected from Ganges River Floodplain (Rajshahi District, Bangladesh) which soil types predominantly include calcareous grey floodplain soils. The initial soil pH was 7.9 in water. The basic properties of soil are out-lined in Table 1. The BARI GOM-25 and BARI GOM-26 wheat varieties were used as testing plants.

\section{Design}

The split-root experiment was conducted with the treatments described in Table 2. The BARI GOM 25 and BARI GOM 26 were compared. The treatments were replicated three times. $\mathrm{KH}_{2} \mathrm{PO}_{4}$ chemical was used as $\mathrm{P}$. To avoid the interactions between soil

Table 1 Properties of soils used in different experiments

\begin{tabular}{lllllll}
\hline Soil pH & Total N (\%) & $\begin{array}{l}\text { Available P } \\
(\mathbf{p p m})\end{array}$ & $\begin{array}{l}\text { Exchangeable K } \\
(\mathbf{C m o l} / \mathbf{k g})\end{array}$ & $\begin{array}{l}\text { Available S } \\
(\mathbf{p p m})\end{array}$ & $\begin{array}{l}\text { Available Zn } \\
(\mathbf{p p m})\end{array}$ & $\begin{array}{l}\text { Organic matter } \\
(\%)\end{array}$ \\
\hline 7.9 & 0.03 & 14.3 & 0.21 & 5.6 & 11.55 & 0.55 \\
\hline
\end{tabular}


Table 2 Split-root system with different treatments

\begin{tabular}{|c|c|c|c|c|c|}
\hline \multirow[t]{2}{*}{ Treatment } & \multirow[t]{2}{*}{ Symbols } & \multicolumn{2}{|c|}{ Treatment symbols } & \multicolumn{2}{|l|}{ P level } \\
\hline & & Compartment 1 & Compartment 2 & $\begin{array}{l}\text { Compartment } 1 \\
\text { (mg P/kg) }\end{array}$ & $\begin{array}{l}\text { Compartment } 2 \\
(\mathrm{mg} \mathrm{P} / \mathrm{kg})\end{array}$ \\
\hline A & $\mathrm{OP} / \mathrm{OP}$ & $\mathrm{OP}$ & $\mathrm{OP}$ & 0 & 0 \\
\hline B & $10 \mathrm{P} / 50 \mathrm{P}$ & $10 \mathrm{P}$ & $50 P$ & 10 & 50 \\
\hline C & $50 P / 200 P$ & $50 P$ & $200 P$ & 50 & 200 \\
\hline
\end{tabular}

nutrients and added P, no basal nutrients were added. The plants were allowed to grow for 28 days and they had to depend on the reserved food of the seeds and the added $\mathrm{P}$ for their growth.

The soil was incubated at $30{ }^{\circ} \mathrm{C}$ for 7 days, then $\mathrm{KH}_{2} \mathrm{PO}_{4}$ as per $\mathrm{P}$ doses were applied directly to the soil in each cup and mixed thoroughly before sowing. The total experiment was conducted in the Research laboratories, Department of Agronomy and Agricultural Extension Rajshahi University, Rajshahi.

\section{Construction of split-root system}

Pots having two compartments or chambers with a fixed partition-wall at the middle of the pot were used for the treatment. Each compartment was filled with $500 \mathrm{~g}$ of experimental soil. The soil was compacted. The whole split root system with soil and plant was continued for 28 days.

\section{Crop management}

\section{Seed germination and seedling preparation}

Seeds of uniform size were selected for germination. The seeds of BARI GOM-25 and BARI GOM-26 were germinated in moist sand in two separate trays in dark at $25^{\circ} \mathrm{C}$ for $70 \mathrm{~h}$. To produce young seedlings, the germinated seeds were allowed to grow for 5 days in those separate trays.

\section{Cultivation of plant}

To support the transplanted seedlings, five slots were made on each side of the partitionwall of the pot. Five days old healthy seedlings, were transplanted. Each seeding bearing four seminal roots, $(6-7 \mathrm{~cm}$ long) after cutting one-uneven root, was taken. A singleseedling was put into each slot keeping two seminal roots in each compartment. Then the roots were covered with the same treated soil and watered immediately after planting. $20 \mathrm{ml}$ water was added to each compartment every day and watering was stopped 3 days before harvesting.

\section{Harvesting}

The experimental plants were harvested 27 days after transplanting. The shoots were cut $0.5 \mathrm{~cm}$ above the base part of the stem uniformly. Then the roots were cut $0.5 \mathrm{~cm}$ below the base part and separated carefully into two halves as previously marked. Soils from two root halves where removed carefully so that the roots could not be tonned or left in the soil. Then the collected bulk soil was air dried and stored in a controlled room 
temperature $\left(25^{\circ} \mathrm{C}\right)$ until analysis. Then the roots were washed with DI water to remove the adhered soil from roots. The washed roots were oven dried at $70{ }^{\circ} \mathrm{C}$ for 3 days. Shoots were also oven dried at the same temperature for the same time. After drying, the root and shoot samples were weighed and stored for analytical experiments.

\section{Lab analysis}

Measurements of soil physical and chemical properties

Soil textural analyses were conducted by using an abbreviated version of the International Pipette method. Clay content was determined by a pipette method after pretreatment with $\mathrm{H}_{2} \mathrm{O}_{2}$ to remove organic matter (Gee and Bauder 1986). The $\mathrm{pH}$ of the soil was determined before incubation in deionised water using a soil-to-solution ratio of 1:2.5. Organic carbon of the soil samples was determined by wet oxidation method (Walkley and Black 1934). Soil organic matter content was determined by multiplying the percent value of organic carbon with the conventional Van-Bemmelen's factor of 1.724 (Piper 1950). The nitrogen content of the soil sample was determined by distilling soil with alkaline potassium permanganate solution (Subbiah and Asija 1956). The distillate was collected in $20 \mathrm{ml}$ of $2 \%$ boric acid solution with methylred and bromocresol green indicator and titrated with $0.02 \mathrm{~N}$ sulphuric acid $\left(\mathrm{H}_{2} \mathrm{SO}_{4}\right)$ (Podder et al. 2012). Soil available $S$ ( $\mathrm{ppm}$ ) was determined by calcium phosphate extraction method with a spectrophotometer at $535 \mathrm{~nm}$ (Petersen 1996). The soil available $\mathrm{K}$ was extracted with $1 \mathrm{~N} \mathrm{NH}_{4} \mathrm{OAC}$ and determined by an atomic absorption spectrometer (Biswas et al. 2012). The available $P$ of the soil was determined by spectrophotometer at a wavelength of $890 \mathrm{~nm}$. The soil sample was extracted by Olsen method with $0.5 \mathrm{M} \mathrm{NaHCO}_{3}$ as outlined by Huq and Alam (2005). $\mathrm{Zn}$ in the soil sample was measured by an atomic absorption spectrophotometer (AAS) after extracting with DTPA (Soltanpour and Workman 1979).

\section{Phosphorus determination in soil and plant tissue}

The amounts of $\mathrm{P}$ in root, shoot and soil were determined. After digestion in a mixture of concentrated nitric and percloric acids (4:1), the concentration of $\mathrm{P}$ in root and shoot materials were determined using the vanadomolybdate method after digestion in a mixture of concentrated nitric and perchloric acids (4:1) (Zheng et al. 2005). Colorimetric method for the determination of phosphorous concentrations in digest solutions was used. This method is called the molydovanado-phosphate method (AOAC 1975). Briefly, phosphorous was assayed using the molydovanado-phosphate method adding 3- $\mathrm{ml}$ digested solution, 2-ml reagent and 5-ml DI water. The absorbance reading was used at $470 \mathrm{~nm}$ (Iqbal et al. 2010).

\section{Statistical analysis}

Shoot parameters were analysed by two-way ANOVA (Treatment $\times$ Variety) and root parameters were analysed by three-way ANOVA (Treatment $\times$ Variety $\times$ compartment), total $\mathrm{P}$ uptake as well as distribution of $\mathrm{P}$ in different plant parts were determined by one-way ANOVA using Genstat 11th edition for Windows (Lawes Agricultural Trust, $\mathrm{UK})$. 


\section{Results}

All the plant growth and P-uptake parameters were highly significant $(P \leq 0.001)$ under $P$ levels (Table 3). Similarly, significant differences among varieties were observed in relation to all the growth and P-uptake parameters.

\section{Effect on plant height}

Plant height is a genetic character of a variety but its potential can be achieved by adequate crop management. The data on the effect of different P levels on plant height is given in Fig. 1. The results showed for the variety Bari GOM 25 that the maximum plant height $(30.76 \mathrm{~mm})$ was recorded in treatment $C(50 \mathrm{P} / 200 \mathrm{P} \mathrm{mg} / \mathrm{kg})$, while it was minimum $(23.87 \mathrm{~mm})$ in treatment A (control). Again, the results showed for the variety Bari GOM 26 that the maximum plant height $(30.99 \mathrm{~mm})$ was recorded in treatment C $(50 \mathrm{P} / 200 \mathrm{P} \mathrm{mg} / \mathrm{kg})$, while it was minimum $(25.13 \mathrm{~mm})$ in treatment A (control). Plant height was significantly $(P \leq 0.001)$ affected among all the various $P$ applications and variety of wheat plants. It also increased with the increasing level of phosphorus application. Hence, among low level of various phosphorous application, Phosphate had the gradual increasing effect on plant height with increasing $\mathrm{P}$ applications, while at high level P resulted in maximum plant height.

Table 3 Significance levels for the main and interactive effect of $P$ and varieties on seedlings growth

\begin{tabular}{llllll}
\hline Source of variation & Plant height & $\begin{array}{l}\text { Shoot dry } \\
\text { weight }\end{array}$ & $\begin{array}{l}\text { P concentration } \\
\text { in shoot }\end{array}$ & $\begin{array}{l}\text { Root dry } \\
\text { weight }\end{array}$ & P uptake in root \\
\hline Treatment $(T)$ & $* * *$ & $* * *$ & $* * *$ & $* * *$ & $* * *$ \\
Variety $(\mathrm{V})$ & $* * *$ & n.s. & $* * *$ & $* *$ & $* * *$ \\
Compartment (C) & - & - & - & $* * *$ & $* * *$ \\
$T \times V$ & $* * *$ & n.s. & $* * *$ & n.s. & n.s. \\
$T \times C$ & - & - & - & $* * *$ & $* * *$ \\
$C \times V$ & - & - & - & n.s. & n.s. \\
$T \times V \times C$ & - & - & - & n.s. & n.s. \\
\hline
\end{tabular}

n.s., ${ }^{* *},{ }^{* * *}$ Probability of $>0.05, \leq 0.01$ and $\leq 0.001$, respectively, and ${ }^{\prime}-{ }^{\prime}($ dash $)$ indicates no data available

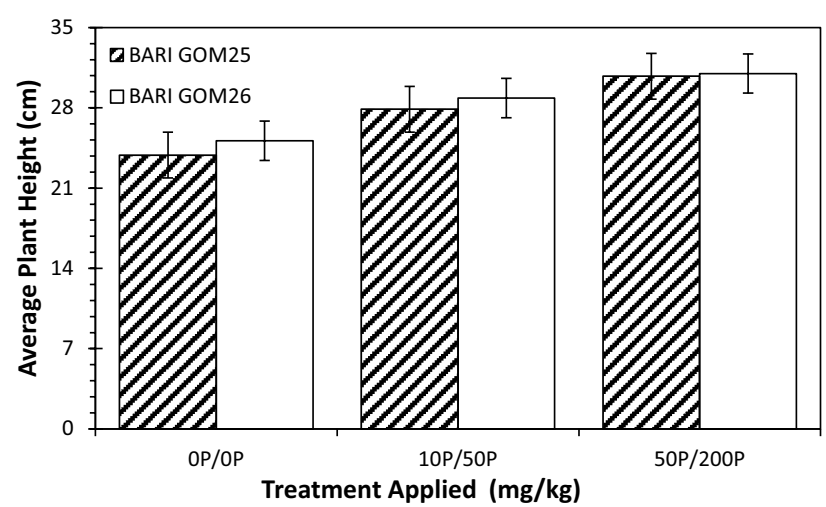

Fig. 1 Effect of $\mathrm{P}$ application on average plant height of the wheat seedlings grown in various level of $\mathrm{P}$ for 28 days 


\section{Shoot dry weight}

Like plant height, the shoot biomass showed similar trend under different $\mathrm{P}$ applications. The results showed for the variety Bari GOM 25 that the maximum shoot biomass $(0.60 \mathrm{~g} / \mathrm{pot})$ was recorded in treatment $\mathrm{C}(50 \mathrm{P} / 200 \mathrm{P} \mathrm{mg} / \mathrm{kg})$, while it was minimum $(0.40 \mathrm{~g} / \mathrm{pot})$ in treatment A (control). Again, the results showed for the variety Bari GOM 26 that the maximum shoot biomass $(0.62 \mathrm{~g} /$ pot $)$ was recorded in treatment $\mathrm{C}$ $(50 \mathrm{P} / 200 \mathrm{P} \mathrm{mg} / \mathrm{kg})$, while it was minimum $(0.42 \mathrm{~g} / \mathrm{pot})$ in treatment A (control). The shoot biomass was significantly $(P \leq 0.001)$ affected among all the various $P$ applications on wheat plant. The shoot biomass did not significantly $(P>0.05)$ differ between varieties of wheat plants. The shoot biomass also increased with the increased level of phosphorus application (Fig. 2).

\section{Root dry weight}

Total root biomass varied among the treatments. Total root biomass of Bari GOM 26 in Treatment C on compartment II (200 $\mathrm{mg} / \mathrm{kg}$ P) was highest $(0.57 \mathrm{~g} / \mathrm{pot})$ and lowest in Treatment A-II $(0 \mathrm{mg} / \mathrm{kg}$ P) $(0.23 \mathrm{~g} / \mathrm{pot})$, followed by gradual increase in the Treatment A-I $(0 \mathrm{mg} / \mathrm{kg} \mathrm{P})(0.26 \mathrm{~g} / \mathrm{pot})$,Treatment B-I $(10 \mathrm{mg} / \mathrm{kg} \mathrm{P})(0.32 \mathrm{~g} / \mathrm{pot})$, Treatment B-II $(50 \mathrm{mg} / \mathrm{kg} \mathrm{P})(0.46 \mathrm{~g} / \mathrm{pot})$ and Treatments C-I $(50 \mathrm{mg} / \mathrm{kg} \mathrm{P})(0.47 \mathrm{~g} / \mathrm{pot})$ (Fig. 3). Again,

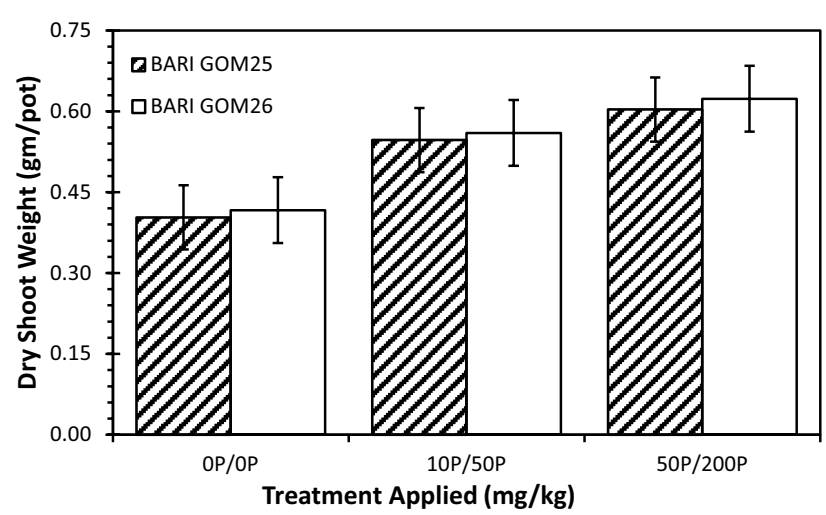

Fig. 2 Effect of $P$ application on dry shoot weight of the wheat seedlings grown in various level of $P$ for 28 days

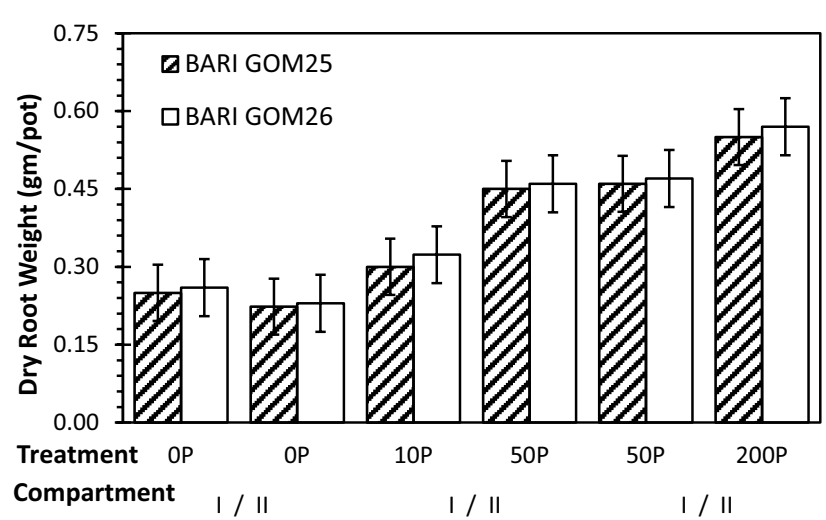

Fig. 3 Effect of $P$ application on dry root weight of the wheat seedlings was grown in various level of $P$ for 28 days 
for Bari GOM 25 total root biomass was highest in Treatment $\mathrm{C}$ on compartment II $(200 \mathrm{mg} / \mathrm{kg}$ P) $(0.55 \mathrm{~g} / \mathrm{pot})$ and lowest in Treatment A-II $(0 \mathrm{mg} / \mathrm{kg} \mathrm{P})(0.22 \mathrm{~g} / \mathrm{pot})$, followed by gradual increase in the Treatment A-I $(0 \mathrm{mg} / \mathrm{kg} \mathrm{P})(0.25 \mathrm{~g} / \mathrm{pot})$, Treatment B-I $(10 \mathrm{mg} / \mathrm{kg}$ P) $(0.30 \mathrm{~g} / \mathrm{pot})$, Treatment B-II $(50 \mathrm{mg} / \mathrm{kg}$ P) $(0.45 \mathrm{~g} / \mathrm{pot})$ and Treatments C-I $(50 \mathrm{mg} / \mathrm{kg} \mathrm{P})(0.46 \mathrm{~g} / \mathrm{pot})$. Similar to shoot dry weight, root biomass was significantly $(P \leq 0.001)$ affected among all the various $P$ application on wheat plant. But, the root biomass affected moderately $(P \leq 0.01)$ between two varieties of wheat plants. The root biomass also increased with the increasing level of phosphorus application.

\section{Shoot $\mathrm{P}$ concentration}

In general, shoot $\mathrm{P}$ concentration was found in increasing trend under different $\mathrm{P}$ application on wheat plant. Shoot $P$ concentration was significantly $(P \leq 0.001)$ affected among all the various $\mathrm{P}$ applications on wheat plant. Total shoot $\mathrm{P}$ concentrations in BARI GOM 26 was the highest and the lowest in Treatment C $(50 \mathrm{P} / 200 \mathrm{P} \mathrm{mg} / \mathrm{kg})$ $(4.27 \mathrm{~g} / \mathrm{kg})$ and Treatment $\mathrm{A}(\mathrm{OP} / 0 \mathrm{P} \mathrm{mg} / \mathrm{kg})(0.40 \mathrm{~g} / \mathrm{kg})$ respectively, but intermediate in Treatments B (10P/50P mg/kg) (1.69 g/kg) (Fig. 4). Again, for BARI GOM 25 total shoot $\mathrm{P}$ concentrations was the highest and the lowest in Treatment $\mathrm{C}(50 \mathrm{P} / 200 \mathrm{P} \mathrm{mg} /$ $\mathrm{kg})(4.02 \mathrm{~g} / \mathrm{kg})$ and Treatment A $(0 \mathrm{P} / 0 \mathrm{P} \mathrm{mg} / \mathrm{kg})(0.39 \mathrm{~g} / \mathrm{kg})$ respectively, but intermediate in Treatments B $(10 \mathrm{P} / 50 \mathrm{P} \mathrm{mg} / \mathrm{kg})(1.67 \mathrm{~g} / \mathrm{kg})$. The shoot P concentration of BARI GOM 25 and BARI GOM 26 were dependent on the treatments. However, the two varieties had similar responses on shoot $\mathrm{P}$ concentration in the different treatments.

\section{Root $\mathrm{P}$ concentration}

In general, root $\mathrm{P}$ concentration was found in increasing trend under different $\mathrm{P}$ application on wheat plant. Root $P$ concentration was significantly $(P \leq 0.001)$ affected among all the various $\mathrm{P}$ applications on wheat plant. Total root $\mathrm{P}$ concentrations in BARI GOM 26 was the highest and the lowest in Treatment $C$ in compartment II $(200 \mathrm{mg} / \mathrm{kg} \mathrm{P})$ $(2.97 \mathrm{~g} / \mathrm{kg})$ and Treatment A-II $(0 \mathrm{mg} / \mathrm{kg}$ P) $(0.28 \mathrm{~g} /$ plant $)$ respectively, followed by gradual increase in Treatment A-I (0 mg/kg P) $(0.29 \mathrm{~g} / \mathrm{plant})$, Treatment B-I $(10 \mathrm{mg} / \mathrm{kg} \mathrm{P})$ (0.47 g/plant), Treatment B-II (50 mg/kg P) (1.38 g/plant) and Treatments C-I (50 mg/ kg P) (1.53 g/plant) (Fig. 5). Again, for BARI GOM 25 total root P concentrations was the highest and the lowest in Treatment $C$ in compartment II $(200 \mathrm{mg} / \mathrm{kg} \mathrm{P})(2.89 \mathrm{~g} / \mathrm{kg})$

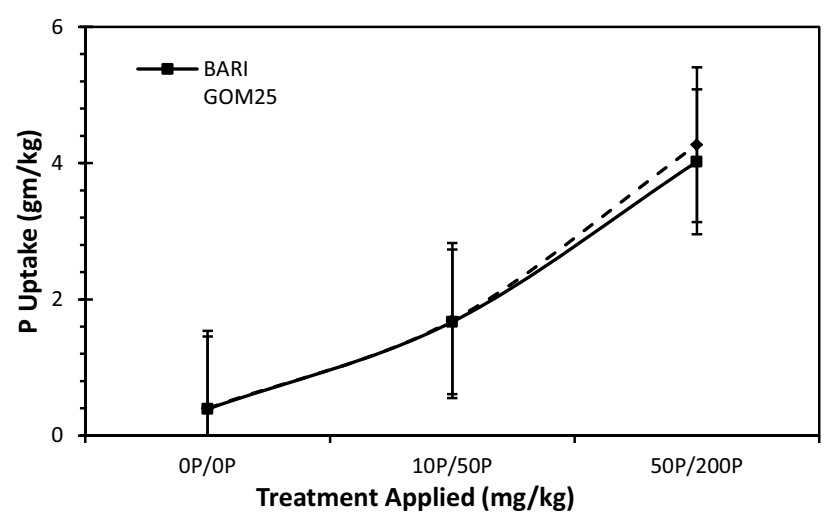

Fig. 4 Effect of $P$ application on $P$ uptake of wheat shoot in various level of $P$ for 28 days 


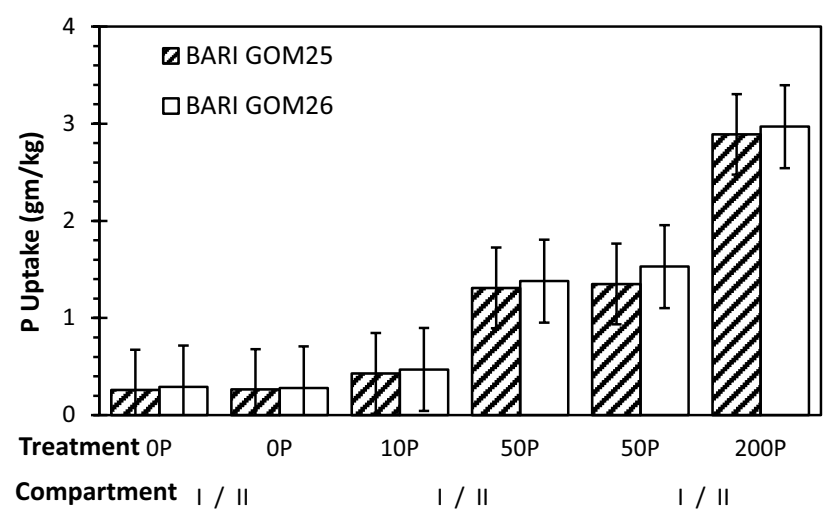

Fig. 5 Effect of $\mathrm{P}$ application on $\mathrm{P}$ uptake of wheat root in various level of $\mathrm{P}$ for 28 days

and Treatment A-I ( $0 \mathrm{mg} / \mathrm{kg}$ P) $(0.26 \mathrm{~g} / \mathrm{plant})$ respectively, followed by gradual increase in Treatment A-II $(0 \mathrm{mg} / \mathrm{kg} \mathrm{P})(0.27 \mathrm{~g} /$ plant $)$, Treatment B-I $(10 \mathrm{mg} / \mathrm{kg}$ P) $(0.43 \mathrm{~g} / \mathrm{plant})$, Treatment B-II $(50 \mathrm{mg} / \mathrm{kg} \mathrm{P})(1.31 \mathrm{~g} / \mathrm{plant})$ and Treatment C-I $(50 \mathrm{mg} / \mathrm{kg}$ P) $(1.35 \mathrm{~g} /$ plant). The root $\mathrm{P}$ concentration of BARI GOM 25 and BARI GOM 26 were dependent on the treatments. However, the two varieties had similar responses on root $\mathrm{P}$ concentration in the different treatments.

\section{Total $\mathrm{P}$ uptake and $\mathrm{P}$ distribution}

In both varieties of BARI GOM 25 and BARI GOM 26 similar trend in total P uptake were found. The total $\mathrm{P}$ uptake by plant was significantly high in Treatment $\mathrm{C}$ $(50 \mathrm{P} / 200 \mathrm{P} \mathrm{mg} / \mathrm{kg})$ from other treatments in both varieties. However, total $\mathrm{P}$ uptake was more than eight times greater in Treatment C $(50 \mathrm{P} / 200 \mathrm{P} \mathrm{mg} / \mathrm{kg})$ than control Treatment A $(0 \mathrm{P} / 0 \mathrm{P} \mathrm{mg} / \mathrm{kg})$. The total P uptake was greater in BARI GOM 26 than BARI GOM 25 in all treatments. Total P uptake in BARI GOM 26 of Treatment C (50P/200P mg/ $\mathrm{kg})$ and Treatment $\mathrm{A}(\mathrm{OP} / \mathrm{OP} \mathrm{mg} / \mathrm{kg})$ were the highest $(8.77 \mathrm{~g} / \mathrm{kg})$ and the lowest $(0.97 \mathrm{~g} /$ $\mathrm{kg}$ ) respectively, and intermediate in Treatments B (10P/50P mg/kg) $(3.54 \mathrm{~g} / \mathrm{kg})$ (Fig. 6). Again, for BARI GOM 25 total P uptake in Treatment C $(50 \mathrm{P} / 200 \mathrm{P} \mathrm{mg} / \mathrm{kg})$ and Treatment A $(0 \mathrm{P} / 0 \mathrm{P} \mathrm{mg} / \mathrm{kg})$ were the highest $(8.26 \mathrm{~g} / \mathrm{kg})$ and the lowest $(0.92 \mathrm{~g} / \mathrm{kg})$ respectively, and intermediate in Treatments B (10P/50P mg/kg) $(3.41 \mathrm{~g} / \mathrm{kg})$.

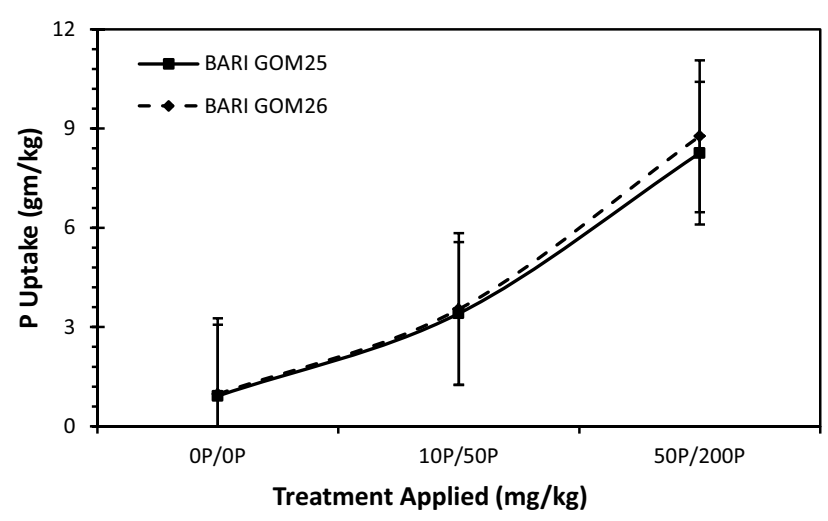

Fig. 6 Effect of P application on P uptake of wheat plant in various level of P for 28 days 


\section{Discussion}

\section{Growth response of wheat plant in split root system}

Plants typically respond to $\mathrm{P}$ limitation by reducing total plant biomass, and diverting resources disproportionately towards root growth (Zhu et al. 2005; Zhu and Lynch 2004). In many soil types, $P$ is localized to the upper soil layers and immobilized with other molecules (Chu and Chang 1966). It is predicted that under limiting phosphorous condition, plants that proliferate roots into these upper layers outperform varieties with deeper root systems (Zhu et al. 2005; Zhu and Lynch 2004). Root proliferation and greater uptake per unit of root in the nutrient-rich zones are often considered to be compensatory responses. According to Raghothama et al. (2005) and Rehim et al. (2007), $P$ deficiency is very common in alkaline calcareous soils. So, the study was conducted to examine the influence of plant phosphorus $(\mathrm{P})$ status and $\mathrm{P}$ distribution in the root zone on root $\mathrm{P}$ acquisition and root and shoot growth of wheat (Triticum aestivum L.) in a split-root soil culture in alkaline soil. To investigate growth response of recently BARI released wheat varieties under elevated $\mathrm{P}$ applied condition, all growth measurements, including root biomass, plant height and shoot biomass measures were taken. The highly significant Treatment $(\mathrm{T})$ interaction for plant growth $(P \leq 0.001)$ in this study indicates that the plant growth responses of BARI GOM 25 and BARI GOM 26 seedlings were dependent on the level of added P. In all treatments, there were no significant differences between BARI GOM 25 and BARI GOM 26 seedlings for any growth measurement. Total plant biomass in BARI GOM 26 of Treatment C increased 82 \% (1.66 g/ pot) in comparison with the controlled Treatment A $(0.91 \mathrm{~g} / \mathrm{pot})$. Similarly in Treatment B increased $47 \%$ (1.34 g/pot) in comparison of Treatment A. Again, for BARI GOM 25 total plant biomass in Treatment $\mathrm{C}$ was increased $83 \%$ (1.61 g/pot) in comparison with the controlled Treatment A (0.88 g/pot). Similarly in Treatment B increased $48 \%$ $(1.30 \mathrm{~g} / \mathrm{pot})$ in comparison of Treatment A. Similar trend was found in shoot biomass and root biomass of both wheat plant varieties in this study (Table 4). While internal biomass distribution in shoot and root were found different trend among all treatments (Fig. 7). The shoot biomass was found highest ( $46 \%$ of total plant biomass) in Treatment A of BARI GOM 25, and in Treatment B and Treatment $C$ the percentages were found in deceasing order 42.2 and $37.4 \%$ respectively of total plant biomass. In case of root biomass the trend was found in increasing order in both compartments among all treatments (Table 4). Similarly, in BARI GOM 26 the highest percentage of shoot biomass was found in Treatment A $46.0 \%$ of total plant biomass and in Treatment B and Treatment $\mathrm{C}$ the percentages were found in decreasing order 41.7 and $37.5 \%$ of total plant biomass respectively. In case of root biomass the trend was found in increasing order in both compartments among all treatments (Fig. 7). The inhibitory effect of increasing the P supply to whole root systems on the development of cluster roots of wheat plant (T. aestivum) is well documented (Qifu and Rengel 2008; Pedas et al. 2011; Iqbal 2014). In our split-root study, the percentage distribution differences in the total root and shoot dry weight among the three P treatments are due to elevated P supply which directly interferes with shoot root growth.

The root-shoot ratio is an important factor to understand growth responses of plants under elevated $\mathrm{P}$ applications. The root:shoot ratio of the wheat plant with and without treatments at the various level of P supply were analyzed (Table 5). Comparison of 
Table 4 Total plant biomass, total shoot and root biomass in different plant parts of the split-root system and distribution of biomass in shoot and two separate compartments

\begin{tabular}{|c|c|c|c|}
\hline \multirow[t]{2}{*}{ Plant parts/variety } & \multicolumn{3}{|c|}{ Total plant biomass (g/pot) } \\
\hline & Treatment $\mathrm{A}$ & Treatment B & Treatment C \\
\hline Bari GOM 25 & 0.88 & 1.30 & 1.61 \\
\hline Bari GOM 26 & 0.91 & 1.34 & 1.66 \\
\hline \multicolumn{4}{|c|}{ Total biomass (g/pot) in different plant parts of the split-root system } \\
\hline \multicolumn{4}{|l|}{ Bari GOM 25} \\
\hline Shoot & 0.40 & 0.55 & 0.60 \\
\hline Compartment-I & 0.25 & 0.30 & 0.46 \\
\hline Compartment-II & 0.22 & 0.45 & 0.55 \\
\hline \multicolumn{4}{|l|}{ Bari GOM 26} \\
\hline Shoot & 0.42 & 0.56 & 0.62 \\
\hline Compartment-I & 0.26 & 0.32 & 0.47 \\
\hline Compartment-II & 0.23 & 0.46 & 0.57 \\
\hline \multicolumn{4}{|c|}{ The distribution of biomass (\%) in shoot and roots grown in two separate soil compartments (I and II) } \\
\hline \multicolumn{4}{|l|}{ Bari GOM 25} \\
\hline Shoot & 46.0 & 42.2 & 37.4 \\
\hline Compartment-I & 28.5 & 23.1 & 28.5 \\
\hline Compartment II & 25.5 & 34.7 & 34.1 \\
\hline \multicolumn{4}{|l|}{ Bari GOM 26} \\
\hline Shoot & 46.0 & 41.7 & 37.5 \\
\hline Compartment I & 28.7 & 24.1 & 28.3 \\
\hline Compartment II & 25.4 & 34.2 & 34.3 \\
\hline
\end{tabular}

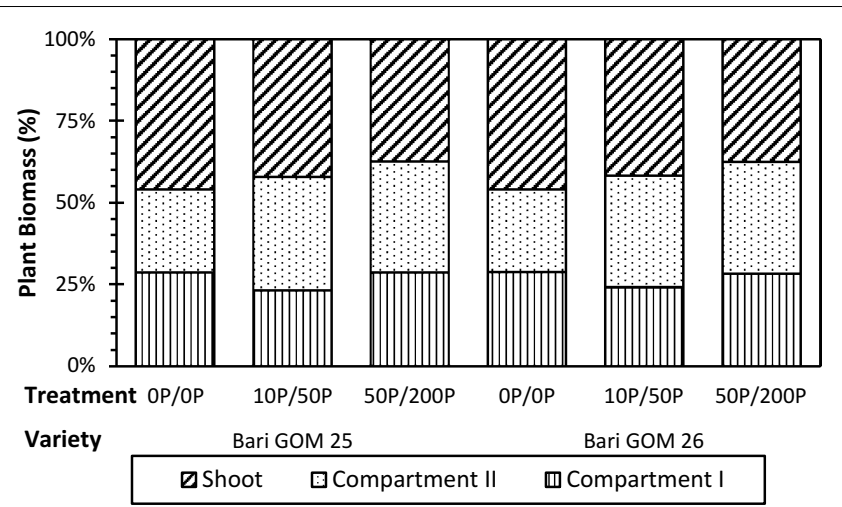

Fig. 7 The distribution of plant biomass in different plant parts of the split-root system

root:shoot ratio of different treatments showed an increase with the increasing P application in both varieties of BARI released wheat plants. In the same line, Shane et al. (2003) reported that, the increase of phosphate supply in root halves influenced the root/shoot ratio of wheat; because root growth increased more than shoot growth. Similar results were observed in wheat plant by Bingham and Bengough (2003) and Qifu et al. (2011).

The relationship between shoot biomass and average plant height was analyzed to determine the effect of plant height on the production of biomass of the wheat plant. A significant correlation $\left(R^{2}=0.97, P<0.05\right)$ between plant height and shoot biomass under elevated $\mathrm{P}$ supply indicates that plant development enhances with the application 
Table 5 Root biomass, shoot biomass, and root/shoot ratio of two wheat varieties across different $P$ applications

\begin{tabular}{llllll}
\hline Variety & Treatment & P rate $(\mathbf{m g} / \mathbf{k g})$ & \multicolumn{2}{l}{$\begin{array}{l}\text { Biomass production } \\
\text { (mg/plant) }\end{array}$} & Root-shoot ratio \\
\cline { 3 - 4 } & & & Shoot & Root & \\
\hline Bari GOM 25 & $\mathrm{T} 1$ & OP/OP & 0.40 & 0.47 & 1.17 \\
& $\mathrm{~T} 2$ & 10P/50P & 0.55 & 0.75 & 1.37 \\
& $\mathrm{~T} 3$ & 50P/200P & 0.60 & 1.01 & 1.67 \\
Bari GOM 26 & $\mathrm{T} 1$ & OP/OP & 0.42 & 0.49 & 1.18 \\
& $\mathrm{~T} 2$ & 10P/50P & 0.56 & 0.78 & 1.40 \\
& $\mathrm{~T} 3$ & 50P/200P & 0.62 & 1.04 & 1.67 \\
\hline
\end{tabular}

of $P$ in soil (Fig. 8). Similarly, a significant correlation $\left(R^{2}=0.99, P<0.05\right)$ between plant height and root biomass under elevated $P$ application was observed. The increase in plant growth is largely due to increase absorption of nutrients from soil solution (Son and Smith 1988). However, the elevated P plays significant role in the growth of the wheat plant.

\section{P distribution and translocation in wheat plant within split-root system}

In general, plants grow better when partially soluble phosphate is applied in comparison to the soluble P source. The study was conducted in alkaline soil and P doses were
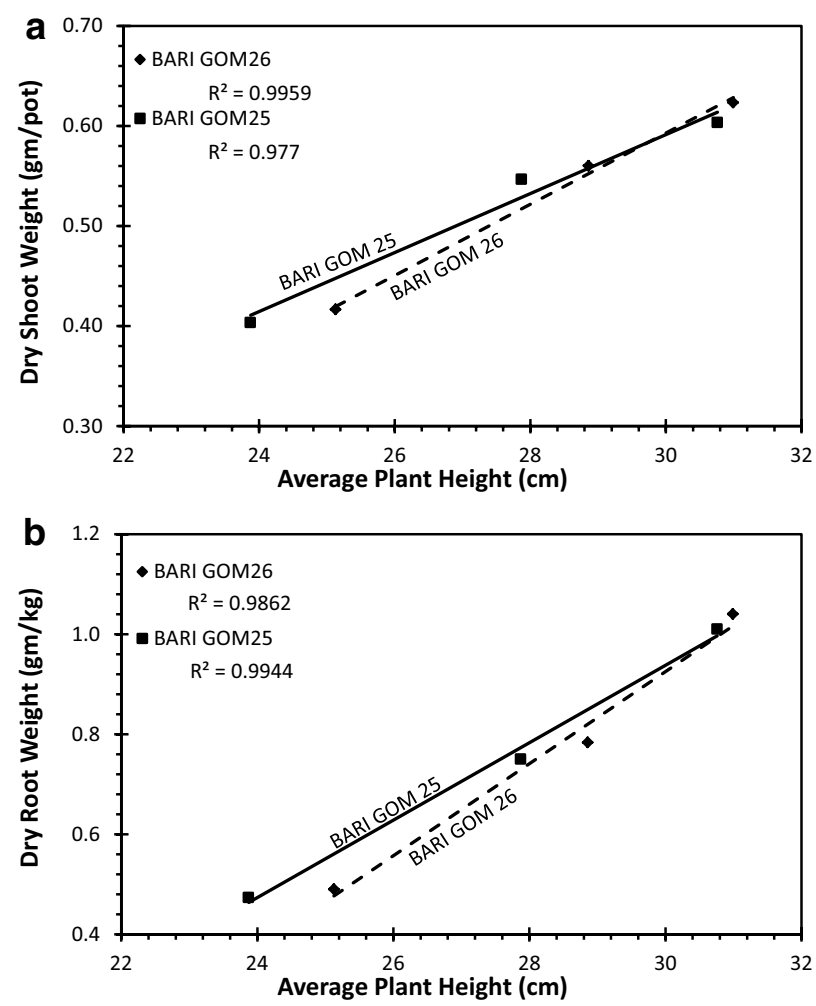

Fig. 8 Relationship between a shoot dry weight and average plant height; $\mathbf{b}$ root dry weight and average plant height of wheat plant 
applied directly to the soil. Hence, the shoot and root $\mathrm{P}$ concentration were found in increasing trend under different $\mathrm{P}$ application on wheat plant. Shoot and root $\mathrm{P}$ concentration were significantly $(P \leq 0.001)$ affected among all the various $P$ applications on wheat plants. Again, similar trends in total $P$ uptake were found in both varieties of BARI GOM 25 and BARI GOM 26. Total plant P concentration in BARI GOM 25 of Treatment $C$ increased more than 8 times $(8.26 \mathrm{~g} / \mathrm{kgt})$ in comparison with the controlled Treatment A $(0.92 \mathrm{~g} / \mathrm{kg})$. Similarly in Treatment B, total plant P concentration increased more than three times $(3.41 \mathrm{~g} / \mathrm{kg})$ in comparison with Treatment A. Again, for BARI GOM 26, total plant biomass in Treatment C increased 9 times $(8.77 \mathrm{~g} / \mathrm{kg})$ in comparison with the controlled Treatment A $(0.97 \mathrm{~g} / \mathrm{kg})$. Similarly in Treatment B, the total biomass increased more than 3 times $(3.54 \mathrm{~g} / \mathrm{kg})$ in comparison with Treatment A. Similar trend was found in shoot $\mathrm{P}$ concentration and root $\mathrm{P}$ concentration of both wheat plant varieties in this study (Table 6); while internal P uptake by shoot and root was found exactly similar trend among all treatments (Fig. 9). The highest percentages of P uptake by shoot was found in Treatment B of BARI GOM 25, $49.0 \%$ of total plant $\mathrm{P}$ uptake while in Treatment $\mathrm{C}$ and Treatment $\mathrm{A}$ it was found in deceasing order 48.7 and $42.6 \%$ respectively of total plant $P$ uptake. Root $P$ uptake was found in increasing order with increasing P supply in both compartments (Table 6). Similarly, in BARI GOM 26 the highest percentage of P uptake by shoot was found in Treatment C (48.7\% of total plant $\mathrm{P}$ uptake) and in Treatment $\mathrm{B}$ and Treatment $\mathrm{A}$ were found in decreasing order (47.7 and $41.2 \%$ respectively of total plant P uptake). Again, root P uptake was found in increasing order with increasing P supply in both compartments (Fig. 9). This

Table 6 Total $P$ uptake in different plant parts of the split-root system and distribution of $P$ in shoot and root two separate compartments

\begin{tabular}{|c|c|c|c|}
\hline \multirow[t]{2}{*}{ Plant parts/variety } & \multicolumn{3}{|c|}{ Total $P$ uptake $(\mathbf{g} / \mathbf{k g})$} \\
\hline & Treatment A & Treatment B & Treatment C \\
\hline Bari GOM 25 & 0.92 & 3.41 & 8.26 \\
\hline Bari GOM 26 & 0.97 & 3.54 & 8.77 \\
\hline \multicolumn{4}{|c|}{ Total P uptake $(\mathrm{g} / \mathrm{kg})$ in different plant parts of the split-root system } \\
\hline \multicolumn{4}{|l|}{ Bari GOM 25} \\
\hline Shoot & 0.39 & 1.67 & 4.02 \\
\hline Compartment-I & 0.26 & 0.43 & 1.35 \\
\hline Compartment-II & 0.27 & 1.31 & 2.89 \\
\hline \multicolumn{4}{|l|}{ Bari GOM 26} \\
\hline Shoot & 0.40 & 1.69 & 4.27 \\
\hline Compartment-I & 0.29 & 0.47 & 1.53 \\
\hline Compartment-II & 0.28 & 1.38 & 2.97 \\
\hline \multicolumn{4}{|c|}{ The distribution of P (\%) in shoot and roots grown in two separate soil compartments (I and II) } \\
\hline \multicolumn{4}{|l|}{ Bari GOM 25} \\
\hline Shoot & 42.6 & 49.0 & 48.7 \\
\hline Compartment-I & 28.4 & 12.6 & 16.3 \\
\hline Compartment II & 29.0 & 38.4 & 35.0 \\
\hline \multicolumn{4}{|l|}{ Bari GOM 26} \\
\hline Shoot & 41.2 & 47.7 & 48.7 \\
\hline Compartment I & 29.9 & 13.3 & 17.4 \\
\hline Compartment II & 28.9 & 39.0 & 33.9 \\
\hline
\end{tabular}




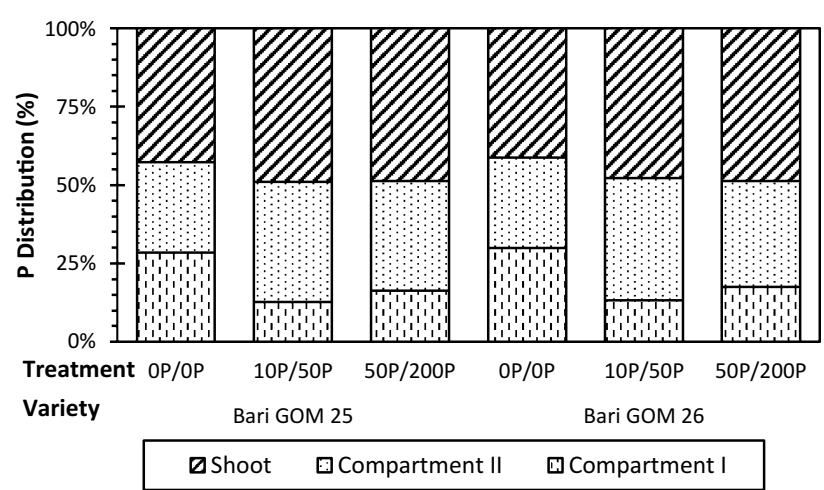

Fig. 9 The P distribution in different plant parts of the split-root system

percentage distribution differences in the total root and shoot $\mathrm{P}$ uptake among the three $\mathrm{P}$ treatments are due to elevated $\mathrm{P}$ supply which directly interferes with shoot root $\mathrm{P}$ status.

Mimura et al. (1996) and Jeschke et al. (1997) described a picture of patterns of inorganic P movement in whole plants. In P-sufficient plants most of the inorganic P absorbed by the roots is transported through the xylem to the younger leaves. Concentrations of inorganic $\mathrm{P}$ in the xylem range from $1 \mathrm{~mm}$ in inorganic P-starved plants to $7 \mathrm{~mm}$ in plants grown in solutions containing $125 \mu \mathrm{m}$ inorganic $\mathrm{P}$ (Mimura et al. 1996). There is also significant retrained location of inorganic $\mathrm{P}$ in the phloem from older leaves to the growing shoots and from the shoots to the roots. In inorganic P-deficient plants the restricted supply of $\mathrm{P}$ to the shoots from the roots via the xylem is supplemented by increased mobilization of stored $\mathrm{P}$ in the older leaves and retranslocation to both the younger leaves and growing roots. This process involves both the depletion of inorganic $P$ stores and the breakdown of organic $P$ in the older leaves. A curious feature of P-starved plants is that approximately one-half of the inorganic P translocated from the shoots to the roots in the phloem is then transferred to the xylem and recycled back to the shoots (Jeschke et al. 1997).

Increase of the external P supply to split root from 0 to $200 \mathrm{mg} \mathrm{P} / \mathrm{kg}$ significantly increased the $\mathrm{P}$ concentration in those roots, and in shoots, but had no significant effect on the P concentration of the controlled roots. This lack of response of controlled roots has been demonstrated in other split-root studies with, e.g. barley (Drew and Saker 1984), subterranean clover (Scott and Robson 1991), tomato (Burleigh and Harrison 1999) and Hakea prostrata (Proteaceae) (Shane et al. 2003). In contrast with the results of split-root plants, the results of our wheat plant split-root study and those of others using foliar spray (e.g. Marschner et al. 1987) demonstrate that $\mathrm{P}$ retranslocated in the phloem sap can result in increased root $\mathrm{P}$ concentrations. In our plants, very high $\mathrm{P}$ supplies (200 mg P/ $\mathrm{kg} \mathrm{KH}_{2} \mathrm{PO}_{4}$ ) to just one crown root of wheat plants significantly increased the $\mathrm{P}$ concentration of compartment-I roots in respect of Treatment B compartment II. It was expected that in Treatment $\mathrm{C}$, plants would be able to translocates $\mathrm{P}$ from the roots in compartment I to those compartment II. Studies with barley (Greenway and Gunn 1966; Clarkson and Scattergood 1982) indicated that P-stressed leaves absorb P more rapidly than control leaves do, and they export much larger amounts to the roots. Higher 
$\mathrm{P}$ concentrations in the shoot of our wheat plants probably provided more $\mathrm{P}$ for shoot unloading of $\mathrm{P}$ and for $\mathrm{P}$ assimilation in the controlled roots, resulting in increased $\mathrm{P}$ concentrations in the roots of wheat plants. In contrast, the split-root technique in alkaline soil probably provides a more stable supply of $\mathrm{P}$ at a lower concentration.

\section{Conclusion}

Considering that $\mathrm{P}$ is an essential and often limiting nutrient for plant growth, it is surprising that many aspects of $\mathrm{P}$ uptake and transport in plants are not thoroughly understood. This study reveals that $\mathrm{P}$ uptake and $\mathrm{P}$ translocation in split root system of the wheat plant in alkaline soil. These findings indicate that the added soluble P increases the absorption of nutrients from the soil solution. However, added P is efficient both for increasing shoot development and root growth. Moreover, no varietal difference is found in various experiments. Again, elevated P concentrations in the shoot of wheat plants probably provided more $\mathrm{P}$ for shoot unloading of $\mathrm{P}$ and for $\mathrm{P}$ assimilation in the controlled roots, resulting in increased $\mathrm{P}$ concentrations in the roots of wheat plants in split root system in alkaline soil. Perhaps the next important leap in our conceptual understanding in this area will come from the integration of these techniques to provide a comprehensive picture of the function of phosphate transporters and how they control their spatial and temporal expression to allow the plant to cope with changing environmental conditions.

\section{Authors' contributions}

RS carried out the whole research and wrote the manuscript; TI supervised the whole research work by providing necessary logistical support and guidance; RS conducted all the experiments, recorded all the data, collected all the samples and conducted lab analysis. Both authors read and approved the final manuscript.

\section{Author details}

${ }^{1}$ Institute of Biological Sciences, Rajshahi University, Rajshahi, Bangladesh. ${ }^{2}$ Department of Agronomy and Agriculture Extension, Faculty of Agriculture, Rajshahi University, Rajshahi, Bangladesh.

\section{Acknowledgements}

The authors are thankful to the Institute of Biological Sciences, Rajshahi University, Rajshahi for providing Post-graduate Research opportunity and Wheat research Centre, Shampur, Rajshahi for providing wheat plants and Soil Resources Development Institute, Shampur, Rajshahi for Testing soil and plants. The authors are also grateful to the Department of Agronomy and Agricultural Extension, Rajshahi University, Rajshahi.

Competing interests

The authors declare that they have no competing interests.

Received: 19 April 2016 Accepted: 12 July 2016

Published online: 20 July 2016

\section{References}

AOAC (1975) Official methods of analysis, 12th edn. Association of Official Analytical Chemists, Washington

Batjes NH (1997) A world data set of derived soil properties by FAO/UNESCO soil unit for global modeling. Soil Use Manag 13:9-16

Bingham IJ, Bengough AG (2003) Morphological plasticity of wheat and barley roots in response to spatial variation in soil strength. Plant Soil 250(2):273

Biswas A, Alamgir M, Haque SMS, Osman KT (2012) Study on soils under shifting cultivation and other land use categories in Chittagong Hill Tracts, Bangladesh. J For Res 12(2):261-265

Burleigh SH, Harrison MJ (1999) The down regulation of Mt4-like genes by phosphate fertilization occurs systemically and involves phosphate translocation to the shoots. Plant Physiol 119:241-248

Chu W, Chang S (1966) Surface activity of inorganic soil phosphorus. Soil Sci 101:459-464. doi:10.1097/00010694-196606000-00007

Clarkson DT, Scattergood CB (1982) Growth and phosphate transport in barley and tomato plants during the development of, and recovery from, phosphate stress. J Exp Bot 33:865-875

Drew MC, Saker LR (1984) Uptake and long distance transport of phosphate, potassium and chloride in relation to internal ion concentrations in barley: evidence of non-allosteric regulation. Planta 60:500-507 
Gee GW, Bauder JW (1986) Particle-size analysis. In: Klute A (ed) Methods of soil analysis. Part 1, 2nd edn. Agron. Monogr. 9. ASA and SSSA, Madison, pp 383-411

Greenway H, Gunn A (1966) Phosphorus retranslocation in Hordeum vulgare during early tillering. Planta 71:43-67

Gyaneshwar P, Parekh LG, Archana G, Podle PS, Collins MD, Hutson HD, Naresh KG (1999) Involvement of a phosphate starvation inducible glucose dehydrogenase in soil phosphate solubilization by Enterobacter asburiae. FEMS Microbiol Lett 171:223-229

Hinsinger P (2001) Bioavailability of soil inorganic $P$ in the rhizosphere as affected by root-induced chemical change: a review. Plant Soil 237:173-195

Huq SMI, Alam MD (2005) A handbook on analyses of soil, plant and water. BACER-DU, University of Dhaka, Bangladesh, pp 13-40

Iqbal T (2014) A split-root experiment shows that translocated phosphorus does not alleviate aluminium toxicity within plant tissue. Plant Soil 384:21-36

lqbal T, Sale P, Tang C (2010) Phosphorus ameliorates aluminium toxicity of Al-sensitive wheat seedlings. In: Proceedings of the 2010 19th world congress of soil science, soil solutions for a changing world. [S.I]:IUSS, Brisbane, pp 92-95

Jeschke W, Kirkby E, Peuke A, Pate J, Hartung W (1997) Effects of P efficiency on assimilation and transport of nitrate and phosphate in intact plants of castor bean (Ricinus communis L.). J Exp Bot 48:75-91

Linkohr BI, Williamson LC, Fitter AH, Leyser HMO (2002) Nitrate and phosphate availability and distribution have different effects on root system architecture of Arabidopsis. Plant J 29:751-760

López-Bucio J, Hernández-Abreu E, Sánchez-Calderón L, Nieto-Jacobo MF, Simpson J, Herrera-Estrella L (2002) Phosphate availability alters architecture and causes changes in hormone sensitivity in the Arabidopsis root system. Plant Physiol 129:244-256

Ma Z, Bielenberg DG, Brown KM, Lynch JP (2001) Regulation of root hair density by phosphorus availability in Arabidopsis thaliana. Plant Cell Environ 24:459-467

Marschner H (1995) Mineral nutrition of higher plants, 2nd edn. Academic Press, New York

Marschner H, Römheld V, Cakmak I (1987) Root-induced changes of nutrient availability in the rhizosphere. J Plant Nutr 10:1175-1184

Mimura T, Sakano K, Shimmen T (1996) Studies on the distribution, re-translocation and homeostasis of inorganic phosphate in barley leaves. Plant Cell Environ 19:311-320

Pedas P, Husted S, Skytte K, Schjoerring JK (2011) Elevated phosphorus impedes manganese acquisition by barley plants. Front Plant Sci 2:37. doi:10.3389/fpls.2011.00037

Péret B, Clément M, Nussaume L, Desnos T (2011) Root developmental adaptation to phosphate starvation: better safe than sorry. Trends Plant Sci 16:442-450

Petersen L (1996) Soil analytical methods soil testing management and development. Soil Resources Development Institute, Dhaka, pp 1-28

Piper CS (1950) Soil and plant analysis. Adelaide University, Hassel Press, Australia, p 368

Podder M, Akter M, Saifullah ASM, Roy S (2012) Impacts of plough pan on physical and chemical properties of soil. J Environ Sci Nat Resour 5(1):289-294

Qifu M, Rengel Z (2008) Phosphorus acquisition and wheat growth are influenced by shoot phosphorus status and soil phosphorus distribution in a split-root system. J Plant Nutr Soil Sci 171(2):266-271

Qifu M, Rengel Z, Siddique Kadambot HM (2011) Wheat and white lupin differ in root proliferation and phosphorus use efficiency under heterogeneous soil P supply. Crop Pasture Sci 62:467-473

Raghothama KG, Sims JT, Sharpley AN (2005) Phosphorus and plant nutrition: an overview. In: Sims JT, Sharpley AN (eds) Phosphorus: agriculture and the environment. American Society of Agronomy-Crop Science Society of America-Soil Science Society of America, Madison, pp 355-378. ISBN-13: 978-0891181576

Rehim A, Abbasi GH, Rashid M, Ranjha AM (2007) Methods of phosphorus application and irrigation schedule influencing wheat yield. Pak J Agric Sci 44:420-423

Ryan P, Delhaize E, Jones D (2001) Function and mechanism of organic anion exudation from plant roots. Annu Rev Plant Physiol Plant Mol Biol 52:527-560

Sánchez-Calderón L, López-Bucio J, Chacón-López A, Cruz-Ramírez A, Nieto-Jacobo F, Dubrovsky JG, Herrera-Estrella L (2005) Phosphate starvation induces a determinate developmental program in the roots of Arabidopsis thaliana. Plant Cell Physiol 46:174-184

Scott BJ, Robson AD (1991) The distribution of Mg, P and K in the split roots of subterranean clover. Ann Bot 67:251-256

Shane MW, De Vos M, De Roock S, Lambers H (2003) Shoot P status regulates cluster-root growth and citrate exudation in Lupinus albus grown with a divided root system. Plant Cell Environ 26:265-273

Smith SE, Jakobsen I, Grønlund M, Smith FA (2011) Roles of arbuscular mycorrhizas in plant phosphorus nutrition: interactions between pathways of phosphorus uptake in arbuscular mycorrhizal roots have important implications for understanding and manipulating plant phosphorus acquisition. Plant Physiol 156:1050-1057

Soltanpour PN, Workman S (1979) Modification of the NH4HCO3-DTPA soil test to omit carbon black. Commun Soil Sci Plant Anal 10:1411-1420

Son CL, Smith SE (1988) Mycorrhizal growth responses: interaction between photon irradiance and phosphorus nutrition. New Phytol 108:305-314

Subbiah BV, Asija GL (1956) A rapid procedure for estimation of available nitrogen in soils. Curr Sci 25:259-260

Tadano T, Sakai H (1991) Secretion of acid phosphatase by the roots of several crop species under phosphorus-deficient conditions. Soil Sci Plant Nutr 37:129-140

Vance CP, Uhde SC, Allan DL (2003) Phosphorus acquisition and use: critical adaptations by plants for securing a nonrenewable resource. New Phytol 157:423-447

Walkley A, Black IA (1934) An examination Degtjareff method for determining soil organic matter and a proposed modification of chromic acid titration method. Soil Sci 37:29-38

Wu SC, Cao ZH, Li ZG, Cheung KC, Wong MH (2005) Effect of biofertilizer containing N-fixer, P and K solubilizers and AM fungi on maize growth: a greenhouse trial. Geoderma 125:155-166 
Zheng JS, Yang JL, He YE, Yu XH, Zhang L, You JF, Shen RF, Matsumoto H (2005) Immobilization of aluminum with phosphorous in roots is associated with high aluminum resistance in buckwheat. Plant Physiol 138:297-303

Zhu J, Lynch JP (2004) The contribution of lateral rooting to phosphorus acquisition efficiency in maize (Zea mays) seedlings. Funct Plant Biol 31:949-958. doi:10.1071/FP04046

Zhu J, Kaeppler SM, Lynch JP (2005) Topsoil foraging and phosphorus acquisition efficiency in maize (Zea mays). Funct Plant Biol 32:749-762. doi:10.1071/FP05005

Submit your manuscript to a SpringerOpen ${ }^{\circ}$ journal and benefit from:

- Convenient online submission

- Rigorous peer review

- Immediate publication on acceptance

Open access: articles freely available online

- High visibility within the field

- Retaining the copyright to your article

Submit your next manuscript at $\boldsymbol{\nabla}$ springeropen.com 